\section{The Western Thoracic Surgical Association}

\section{Announcement of 2006 Annual Meeting}

$\mathrm{T}$ The Thirty-second Annual Meeting of The Western Thoracic Surgical Association will be held June 21-24, 2006, at the Sun Valley Resort in Sun Valley, Idaho. The scientific sessions are open to all duly qualified physicians. Participation in other Association activities for members, invited guests, and program participants will require payment of a social registration fee.

\section{Requests for Meeting Information}

Meeting preregistration and hotel registration forms will be available after January 2006 from:

The Western Thoracic Surgical Association

900 Cummings Center

Suite 221-U

Beverly, MA 01915

978-927-8330; fax: 978-524-8890

wtsa@prri.com

\section{Material for the Program}

Scientific papers will be considered from members and nonmembers. Member sponsorship is not necessary.

For the 2006 Annual Meeting, abstract submission opened on November 14, 2005. All abstracts must be submitted electronically via the WTSA Web site. Information and a link to the submission site was posted on the Web site on November 14. A Call for Abstracts was mailed out around that time. Abstracts of proposed papers must be submitted on or before January 10, 2006.

Successful essayists must send the complete manuscript directly to The Journal of Thoracic and Cardiovascular Surgery and must not exceed 3000 words without illustrations. Electronic submissions are to be sent to: http://jtcvs.editorialmanager.com where complete instructions are also available. The essay length must be reduced appropriately when figures or tables are included.

\section{Samson Resident Prize Essay}

The Association offers a prize for the best manuscript on a topic of interest to thoracic surgeons in honor of Paul C. Samson, MD. Candidates for the prize must be in a training program in the United States or Canada. The one essayist whose abstract, manuscript, and presentation are judged most outstanding will receive a $\$ 2000$ cash award following the presentation of all papers in Sun Valley. The conditions for abstract submission, presentation, and publication as described above will apply. The authors of the abstracts chosen for the program will make up the finalists and will be notified by mid-February 2006 that they must submit six completed manuscripts for review by the Prize Essay Committee. The Prize Essay committee will make its selection following the presentation of all papers.

\section{Application for Membership}

Applications for membership in the Association must be received by the Membership Committee Chairman no later than March 1, 2006, to be considered at the following annual meeting. Applicants must be sponsored by three members of the Association who are not members of the Membership Committee. Application forms will be issued only to sponsoring members.

Address correspondence to:

Chairman, Membership Committee

The Western Thoracic Surgical Association

900 Cummings Center

Suite 221-U

Beverly, MA 01915

978-927-8330; fax: 978-524-8890

wtsa@prri.com

\title{
The American Board of Thoracic Surgery
}

\section{Notices}

$\mathrm{T}$ he part I (written) examination will be held on December 5, 2005. It is planned that this examination will be given at multiple sites throughout the United States using an electronic format. The closing date for registration is August 1 each year. Those wishing to be considered for examination must apply online at www.abts.org.

To be admissible for the Part II (oral) examination, a candidate must have successfully completed the Part I (written) examination.

A candidate applying for admission to the certifying examination must fulfill all the requirements of the Board in force at the time the application is received. Please address all communications to the American Board of Thoracic Surgery, 633 North St Clair Street, Suite 2320, Chicago, IL 60611 (telephone: 312-202-5900).

\section{Requirements for Recertification/Maintenance of Certification}

$\mathrm{D}$ iplomates of the American Board of Thoracic Surgery who plan to participate in the Recertification/Maintenance of Certification process must hold an active medical license and must hold clinical privileges in thoracic surgery. In addition, a valid certificate is an absolute requirement for entrance into the recertification/maintenance of certification process. If your certificate has expired, the only pathway for renewal of a certificate is to take and pass the Part I (written) and the Part II (oral) certifying examinations.

The American Board of Thoracic Surgery will no longer pub- 